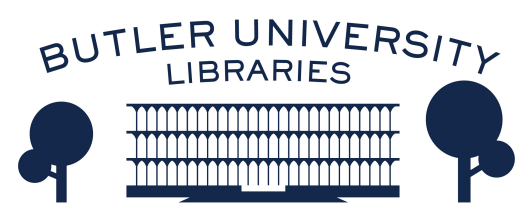

Journal of Hindu-Christian Studies

Volume 20

Article 8

January 2007

\title{
A Woman's Kind of Love: Female Longing in the Tamil Alvar Poetry
}

Archana Venkatesan

Follow this and additional works at: https://digitalcommons.butler.edu/jhcs

Part of the Religion Commons

\section{Recommended Citation}

Venkatesan, Archana (2007) "A Woman's Kind of Love: Female Longing in the Tamil Alvar Poetry," Journal of Hindu-Christian Studies: Vol. 20, Article 8.

Available at: https://doi.org/10.7825/2164-6279.1383

The Journal of Hindu-Christian Studies is a publication of the Society for Hindu-Christian Studies. The digital version is made available by Digital Commons @ Butler University. For questions about the Journal or the Society, please contact cbauman@butler.edu. For more information about Digital Commons @ Butler University, please contact digitalscholarship@butler.edu. 


\title{
A Woman's Kind of Love: Female Longing in the Tamil Alvar Poetry
}

\author{
Archana Venkatesan \\ St. Lawrence University
}

O clouds, spread like blue cloth

across the vast sky--

Has Tirumal my beautiful lord

of Venkatam, where cool streams leap--

come with you?

My tears gather

and spill between my breasts

like waterfalls.

He has destroyed my womanhood.

How does this bring him pride?

Nacciyar Tirumoli $8.1^{1}$

IN the eighth section of Andal's Nacciyar Tirumoli, a woman calls to the clouds and bids them to take a message of love to her delinquent lover, Vishnu, here figured as the lord of Venkatam. In the opening verse of the decad quoted above, she begins by plaintively questioning the clouds of her beloved's whereabouts only to end with' a bitter complaint about her sullied womanhood-pen-nirmai. Bracketed by her eager questions-"has the lord of Venkatam come with you"-and her bitter complaint-" "how does this bring him pride"-is the landscape of her body. Her tears are waterfalls, her breasts mountains, and just as the waterfalls erode the soil from the mountain slopes, her tears erase her womanhood. The black mark against the unrepentant divine lover is not just her (implied) lost chastity, but the gradual corrosion of her very self.

In a similar Tamil Cankam poem (c. $\left.1^{\text {st }} \mathrm{CE}\right)$, which is no doubt the inspiration for the above verse, the talaivi (heroine) has this to say ${ }^{2}$ :

When he said

"I'll go, I'll go,"

I mistook it

For all his former

Mock departures

And I said "Fine,

Leave my side

And go away forever."

ARCHANA VENKATESAN is Assistant Professor of Comparative Literature and Religious Studies at the University of California, Davis. She has a Ph.D. in South Asian Studies with a specialization in Tamil Literature from the University of California, Berkeley. Her research interests are in textual, performance and visual cultures in South India. She has recently been awarded a National Endowment of the Humanities Fellowship to conduct research on hereditary ritual performers at the Vishnu temple at Alvar Tirunagari. 
O Mother

Our master who supports us-

Where is he now

I wonder

The place between my breasts

Has filled up with tears,

And has become a pond

Where a black legged

White heron feeds.

\section{Kuruntokai $325^{3}$}

The most obvious meeting point for both these poems is in the final metaphor, where the body of the heroine becomes the landscape ravaged by unrequited desire. But while the Cankam poem is predicated on a linguistic misunderstanding - what the lover says as a joke (I'll go, I'll go), the beloved takes to be true (then go), for the woman in Andal's poem the terrible punishment is a causeless and unwarranted separation. And, while our Cankam heroine is in a sense responsible for her own tragedy, the heroine of Andal's poem is victim to the whimsy of a cruel and distant god. Ultimately, the sorrow of both women is marked by emptiness and erasure-the loss of womanhood, the sadistic pecking of the heart, the fading of beauty.

Susan Stewart in Poetry and the Fate of the Senses argues that "poetic making is an anthropomorphic project" where the poet creates the figure of the beloved so as to reciprocally recognize one's own figure. ${ }^{4}$ Through engaging the senses-touching, tasting, smelling, seeing - the beloved becomes the mirror, the opposite, the deceptive image of one's own self. But in these poems it would appear that the opposite has happened; the women that inhabit both these poems (and who stand in for a kind of larger-than-life love) threaten to disappear unrecognized by the absent lover. But there is also another kind of anthropomorphizing at work in Andal's poem, where the act of creating the "female persona," this voice of longing also makes the author of the poem. These bhakti (alvar) poets, like skilled ventriloquists, inhabit the foreign bodies of their fictive women, shaping them and lending them the "willed voice of the body." "s

In these poems we hear two voices, and see but one ravaged body-but in the later Srivaishnava commentarial traditions, in the process of allegoresis the voices of the poet and her/his imagined persona will seem as one. And following such a lead, we have a long and revered scholarly tradition that reads the voices of these female characters of Tamil bhakti poems as univocal. In each of these Tamil alvar poems there is essentially the same woman who always finds herself in the undesirable position of rejected lover, bemoaning her unfortunate fate. ${ }^{6}$ But each voice, (even invented ones) like eyes, are the fingerprints of the self and is like no other, marked by the peculiar attentions of the poet that creates her. So this essay is not about the meeting points of alvar poetry and its Cankam akam antecedents. Rather, I am concerned with points of departure, especially in how two alvar poets- Andal and Tirumankaireconfigure the ubiquitous talaivi of the Cankam akam poems to meet the demands of the emergent Tamil bhakti poetry.

\section{Loving God: Meetings and Departures}

Like the Cankam counterparts, the Tamil bhakti poems are peopled with a variety of stock female characters: heroines, mothers, fostermothers, friends, and fortune-tellers. Often, and this is especially true of the two male poets, Nammalvar and Tirumankai, in a kind of Keatsian synaesthasia we hear of the fate of the talaivi through the eyes of these supporting female characters. Nonetheless, mothers, friends and fortune-tellers are but supplementary, the supporting cast to the lovelorn talaivi, who stands at the center of the narrative trajectory. Unlike the Cankam poems, the divine hero (talaivan) is almost entirely absent, evoked in these bhakti verses in a fragmentary fashionhis lips teasing the heroine in the blossoming of the kovai fruit, the sound of his flute suggesting his far away presence. In a sense, the absence that is present in the akam poems as a kind of subtle undertone, becomes full bodied (although it ravages the body of the heroine) in these Tamil bhakti poems. The god does not deign to answer her cries. He offers her no reply, even through insentient things that she might mistakenly assume to be his messenger. These poems are incomplete stories, their happy 
endings provided only by a much later hagiographic tradition. In the bhakti-akam poems (akapporul), the only named male character, Purushottama, that most excellent of men, is entirely absent, and silent-only evoked in the landscape of memory. Here the archetypal hero of the akam genre is merged with that of the benevolent king of the puram (exterior/public) poems, who dispenses justice and just rewards to bards. As Norman Cutler and AK Ramanujan observe, the akam bhakti poems are infused with the spirit of the exterior world of kings and kingship, though bhakti poets who compose in this mode, violate a cardinal principal of akam poetics by naming the nameless hero, identified as either Vishnu or Shiva. ${ }^{7}$

It is therefore only logical that when we plot points of departure between Cankam poetry and Tamil alvar poetry, it is the dramatic reimagining of the hero that captures our attention. Not only is the divine (transcendent) hero of the akapporul bhakti poems, identified by being imbued with local color, but also differentiated by his intimate engagement with a particular site or with particular narratives. The object of desire for the talaivi of the bhakti poem though a singular god is nonetheless particularized while she herself remains archetypal, conventional, undifferentiated. For example, AK Ramanujan titles the akapporul verses in Hymns for the Drowning as though they were translations of Cankam poems, labeling his renditions of Nammalvar's poems as "four returning voices": "what she said," "what her girlfriend," "what her mother said" and so on. ${ }^{8}$ So, while much of scholarly attention (and I just mention Ramanujan as illustrative of this trend) has rightly focused on how god is embodied as lover in these akapporul verses, they have remained curiously silent about the heroine (talaivi), who is vitally present in the poetic situation.

The later Srivaishnava commentators $\left(11^{\text {th }}\right.$ century onwards) are eloquent on the subject of female longing. Whether discussing the alter ego of Nammalvar and Tirumankai or the "authentic voice" of Andal, the Srivaishnava commentators dissolve the fragile barrier between poet and persona to identify the lonely female figure of the bhakti akam poems with the its author. While Tamil poetic grammars guide us into reading the disruptive melancholy of the akam poem such as the one I began this paper with into a continuous narrative cycle of union and separation, the commentaries complete the incomplete poems through a delicate albeit ubiquitous allegoresis: the female lover is the dependent soul and the longed for beloved is the ineffable divine. Thus, the akapporul bhakti poems become in the hands of the skilled exegete, autobiographical and theological. On the one hand, these poems document an individual's ecstatic encounter and on the other, they gesture to the fundamental Srivaishnava principle that all souls are ultimately female with god as the only male. ${ }^{9}$ The Srivaishnava commentaries succeed in straddling two opposing assertions. The female personae (talaivis) of these poets are distinctive, contoured by the interiority of the poet's metaphysical process. But these heroines (talaivis) also act as a metonymy for the souls of all beings; in this latter reading they are doubtless, generic, undifferentiated and shared.

AK Ramanujan in his essay "Where Mirrors are Windows" presents a model that asks us to place South Asian texts into conversation with one another, so that they not only make possible infinite readings, but act as windows into new possibilities. ${ }^{10}$ In this paper, I bring into dialogue the heroines of two kinds of poets - Andal (a woman) and Tirumankai (a man who writes as a woman) - and three poems (two for Andal and one for Tirumankai) to suggest that the fundamental shift that reconfigures the Cankam talaivan (hero) into the divine lover necessitated a reciprocal accommodation for his female counterpart. That is, just as the god without trouble can remain paradoxically local and transcendent, his female lovers, fundamentally ambiguous, are rendered simultaneously universal and particular. Juxtaposing two very different poets (Andal and Tirumankai) and their three very different poems begins to suggest the pliability of the category of the generic talaivi within the context of emergent Tamil bhakti poetics, of which Alvar poetry might be understood as exemplary. But with this new found amplitude with regard to the talaivi character also comes a profound willed ambiguity, where the univocal and universal heroine becomes multi-voiced and particularized 
by the poet that brings her to life, while nonetheless-in a remarkable sleight of handremaining true to her Cankam archetype. The ambivalence inherent to the talaivi of the bhakti akapporul verses is never resolved-she remains an ambiguous figure both particularized by the poet who brings her to life and generalized (and also particularized) by the commentarial tradition that follows.

\section{Heroines for Love: Andal and Tirumankai}

In the alvar corpus only two male poets, Nammalvar and Tirumankai compose extensively in the akam mode, taking on the role of the talaivi. They are joined by the sole female poet, Andal, who too composes, perhaps with no surprise, in the female voice. Of the one thousand odd verses of Nammalvar's Tiruvaymoli, two hundred and seventy dramatize the longing of the talaivi, while all one hundred verses of his impressionistic Tiruviruttam fully develop the akam theme with the heroine at its center. Tirumankai, a poet's poet, experiments with genres, meters and poetic situations and not only does his huge Periya Tirumoli feature a number of decads devoted to the figure of the talaivi, but like Nammalvar he devotes entire poems to the plight of the heroine. The Ciriya and Periya Tirumadal (The Short and Long Madal Poems), and the Tiruneduntandakam (The Long Tandakam) are exemplary of the poetic virtuosity that be brings to molding his women (talaivis) and their maddening predicament. ${ }^{11}$ Andal, distinguished as the sole female poet, composes two poems, the Tiruppavai and Nacciyar Tirumoli, exclusively in the voice of the beloved-in her poems there are no other interlocutors--no mothers, no friends, neither birds nor clouds speak or comment on the heroine's plight. In her poems, they like the gods are silent and cruel spectators, passively observing her gradual decay. It is in this lack of outside poetic comment, and her restraint in exploiting the full complement of akam poetics that Andal stands out amidst her male contemporaries. It is a device, spectacularly effective in rendering the heroine utterly alone, completely without resources to respond to the unfair dalliance of a whimsical god.

\section{God's Bride: Andal}

Andal, who is the $9^{\text {th }}$ century poet Kotai, composed two poems, the short thirty verse Tiruppavai and the longer Nacciyar Tirumoli. In the first poem, she imagines herself as one of many gopi girls undertaking a quest to win an enigmatic drum (parai) from Krishna. The poem begins with a presumably female voice calling these gopi girls to undertake a special kind of vow during the month of Margali (DecemberJanuary), though it is unclear who the speaker of the poem is:

It is the month of Margali:

the moon is full and the day auspicious.

Come to bathe in the waters,

You precious girls, richly adorned

dear to Ayarpadi,

land of abounding prosperity.

Centuries of commentarial tradition direct us to insert Andal into the poem, specifically as the leader of the retinue of questing girls, though it is actually unclear where she has positioned herself in the poem. That is, has Andal (as the final verse seems to indicate) imagined a situation where gopi girls undertook such a quest? Or is she imagining herself as one of the questing girls? Or-and this is the least likely scenario-is she describing a vow that she actually undertook? Periyavaccan Pillai, the thirteenth century Srivaishnava commentator and theologian, in his introductory comments to the poem, agrees that it is unclear if Andal undertook the pavai vow, is pretending to be a gopi girl undertaking such a vow, or if she is imagining a situation in which gopi girls observed the vow. He happily resolves not to resolve the question and conflates Andal with the gopis. The situation is further complicated by the plural "we" that runs through the poem. The girls are a chorus of voices; they plead with Krishna: give $u s$ the drum, we have come to you, may we be devoted to you forever. For example, despite the collective voice of the Tiruppavai, Andal is not only identified as one of their girls, but as the exemplary girl, the leader of the 
tenacious group of questing gopis. In the choir, it is her voice that rises above all the others, clear and resolute.

But, this is what Andal has to say in the final $\left(30^{\text {th }}\right)$ verse of the Tiruppavai, about the poetic situation:

The pattar of lovely Putuvai

who wears a garland of pure, cool lotuses-his Kotai, sang a garland of thirty songs in Cankam Tamil, about the cowherd women with faces bright as the moon who adorned in beautiful jewels won the parai --drum, worshipping Keshava, that very Madhava who churned the ocean of milk with its many ships

For the poet, here, Andal, there appears to be no ambiguity; she has sung a song about cowherd girls, but is actually not one of those girls. She creates the personae of the earnest gopis in pursuit of the parai drum and Krishna. The girls of the Tiruppavai are no retiring creatures. Wheedling their way past guards, they boldly enter Krishna's house, peer into his bedroom and demand to be allowed to share in the special intimacy of lover and beloved. The Srivaishnava commentators attribute such excessive boldness to their love for Krishna, which cannot be constrained by mortal and moral rules of behavior.

Now, if we turn to the longer Nacciyar Tirumoli, like Krishna multiplying to accommodate all the gopis, Andal generates multiple identities to reflect the kaleidoscopic scape of her longing. The Nacciyar Tirumoli, chronologically linked to the Tiruppavai, opens with another vow, this one to Kama, but without the aid of a choiric we of the former poem. Whereas the Tiruppavai is a poem about an imagined community of gopis, the Nacciyar Tirumoli is a profoundly intimate journey into the interior. Dennis Hudson has argued convincingly that while it is the Tiruppavai that occupies an exalted place in the liturgical canon of Srivaishnavas, it is the Nacciyar Tirumoli that contours her life. ${ }^{12}$ Andal hagiographies make his point amply as they quote almost exclusively from the Nacciyar Tirumoli to stress her abiding love for Vishnu. It would therefore appear (at least on the basis of the commentaries) that to hear the Nacciyar Tirumoli is to listen to Andal. But things are not so simple. In the second, third and fourth section of the Nacciyar Tirumoli the chorus of gopi girl voices returns. Once again, they are in Vrindavana, chastising Krishna for breaking their sandcastles, stealing their clothes; and then divining their future. Here, I give two examples to illustrate the point. The first is a famous verse from Nacciyar Tirumoli 1, which is quoted in hagiographies to highlight Andal's singular commitment to Vishnu; the second example is from the section that immediately follows:

O Manmatha! My voluptuous breasts swell For that lord alone who holds aloft flaming discus and conch.

If there is even mere talk of offering this, my body to mortal men, then I cannot live.

It is equal in violence to a forest jackal stealthily entering and sniffing at the sacrificial food the learned brahmans--the holders of the Vedas, Offer to the gods in heaven. Nacciyar Tirumoli 1.4

O Narayana! Praised with a thousand names!

O Nara! Raised as Yashoda's son!

We are unable to escape the troubles

You inflict upon us.

The time of pankuni is here,

We have adorned and paved the streets for Kamadeva

Do not be wicked, now, O Sridhara!

Do not break our sandcastles!

Nacciyar Tirumoli 2.1

The singular voice (I) of the fourth verse of the first section gives way to the plural (we) of the Nacciyar Tirumoli 2 and remains for the next two sections of the poem. But this hide-and-seek with the heroine is not unique to these opening sections. The "I" returns in the fifth decad of the poem and remains until the very end of the 
poem, where the gopi girls once again make their appearance in Vrindavana. Andal's alteration between "her" voice and the identity of the gopi girls says something significant about the ways in which the female voice may be used and understood in alvar poetry. The voice of the gopi (certainly a generic character) is always a collective voice and acts as a counterpoint to the lament of the individual that comprises the majority of the Nacciyar Tirumoli. The collective gopi voice invariably emerges in Andal's poetry in the mythic world of Vrindavana, where Krishna remains close at hand, and even when he chooses to disappear, there are those who share the pain brought by separation. The real and material world of sacred sites is lonely, for one such as Andal and the decads of the Nacciyar Tirumoli express this profound and killing solitude by reverting to the unmediated voice of the talaivi. There are no like-minded companions who can empathize with her suffering, who can make sense of an untamed and reckless love. Instead there are unheeding birds, insentient clouds and groups of mothers who appear to simply wring their hands in despair at her fate. It is only in the final (fourteenth section) of the Nacciyar Tirumoli that both voices ('I'and 'we') return in a kind of dialogue conducted across space and time. While the heroine's bitter voice raises questions about Krishna's whereabouts, a collective voice replies that he can be found only in Vrindavana.

Have you seen him?

My lord who snared me

in the web of his cool lotus eyes

drags me everywhere, and toys with me

\begin{abstract}
A mighty elephant calf as if covered in a coat of pearls beaded with sweat playing we glimpsed him thus, in Vrindavan. Nacciyar Tirumoli 14.4
\end{abstract}

It would appear that when the collective voice of the gopi girls emerges in the Nacciyar Tirumoli, it is to signify the possibility of union, only realized in a mythic, perhaps imaginal realm. One bound to the material world, like the heroine of the Nacciyar Tirumoli is condemned to continued, endless separation. When she does experience that momentary union, it is either when she enters the mythical world of Krishna's play or in the universe of dreams, where she (the heroine/ Andal) dreams she marries Vishnu. In the poignant section that follows the talaivi awakens to find that her grand wedding witnessed by the gods was but a cruel deception.

\section{Mad for Vishnu: Tirumankai}

In contrast to Andal, our two male poets, Tirumankai and Nammalvar, do not juxtapose the material and mythic worlds to signify the heroine's (talaivi's) union and separation with the divine. Rather, they employ the full complement of female characters of the akam genre to construct and comment on interior world of their talaivi. In this next section, I turn my attention to Tirumankai's rather conventional akapporul poem (lit. a poem with a love theme), known as the Tiruneduntandakam (The Longer Tandakam).

Tirumankai's

Tiruneduntandakam showcases a heroine who is the very epitome of the akam talaivi. She is the antithesis of the flagrant, boisterous talaivi of Tirumankai's madal poems. Instead, in this poem, she and her unfortunate situation are mediated by the voice of her mother. In the Tiruneduntandakam, Tirumankai imagines his female persona (heroine) through the lens of how a mother sees a daughter who is mad for Vishnu. In the eleventh verse of the Tiruneduntandakam, the mother recounts the fortune-teller who diagnosed the cause of her daughter's sickness as the "lord dark as rain cloud." The mother says:

O Ladies! My fawn-eyed girl has her hair decked with flowers, and bees humming on it. She drapes herself in silk, she swoons. No more does she desire her dolls. With tears welling in her swollen eyes, she seldom goes to sleep. Even for a moment, she does not sit on my lap to be fed. "Where is my lord of Tiruvarangam", she asks. "Who has done this to her?", I asked a soothsayer. "It is the ocean hued lord", she answered. Now who can save my daughter? ${ }^{13}$

\section{Tiruneduntandakam $11^{14}$}


Here the mother is not really concerned with what ails her daughter, but what its cure might be-who indeed can save her daughter. It is a rhetorical question where the implied answer is that nothing can save the girl. The god is of course both the cause of her ailment and its cure, but having given her the terrible disease of unrequited love there is no promise that he will also bring its cure. Towards the end of the poem the girl speaks briefly for the first time in dialogue with an unnamed friend. She speaks of being seduced by the beauty of the beloved without first being aware of his divinity, saying, "we feared that he was a god." Her fear does nothing to slow down the seduction and the eventual separation, all of which occurs in the space of a single verse: the god seduces her with songs and at once her bangles are loose, her waist disappears and her heart surrenders to him. ${ }^{15}$

The Tiruneduntandakam provides two perspectives and two voices on a single situation-the mother who despairs of her daughter's fate and the daughter who comes to a detached acceptance of that same fate. Her concern is primarily the loss of innocence and childhood. Her daughter has lost her modesty fully aware that Lakshmi, inseparable from Vishnu, adorns his chest, implying of course that this pampered girl will never attain her heart's desire. The daughter's (talaivi's) assessment is much the same. The poem ends with her voice pessimistically and emphatically proclaiming that she, who is like a dog, will think upon the god eternally, suggesting of course, that union is impossible and separation inevitable. The talaivi echoes Tirumankai who opens his magnus opus, the Periya Tirumoli, insisting upon his unworthiness; this girl then, is indeed a female Tirumankai, serendipitously possessed by the god but ultimately convinced of her unworthiness for such a blessing. ${ }^{16}$

Perhaps the starkest contrast in the configuration of the talaivi of Andal and Tirumankai is the absence of a multiplicity of other female voices commenting on the heroine's situation. Susan Stewart observes that "the authenticity of the speaker's emotion can be created only in a context of dialogues and a third person point of view,"17 an observation particularly apt to the talaivis of these poems.
Presumably, as a woman Andal can speak of a woman's experience without the need for a kind of third party verification. The multitude of stylized female voices, whether in Tirumankai's madal poems, his Tiruneduntandakam, or in Nammalvar's renditions in Tiruvaymoli become a tool to attest to the authenticity and believability of the heroine's experience. If the mother, the daughter and the fortune-teller adduce the same symptoms to arrive at the same conclusion, it follows that the experience must in fact be true. What we find in alvar poetry then are a variety of ways of constructing the female voice depending on which poet is speaking and where the poet decides to situate/his/her heroine. It suggests that there is not only a variety in the character of the talaivi (Andal and Tirumankai), but also a startling differentiation in how the talaivi is contoured within the corpus of a single poet.

\section{Conclusions}

Martha Selby, in writing against the category of "love poem" in South Asia, suggests that the poems and the means to read these poems are inextricably linked, particularizing the poem (and the reading system) to its linguistic, historical, regional and cultural contexts. ${ }^{18}$ She argues persuasively that despite shared themes, motifs and metaphors, the particularity of the governing aesthetics for each form, their historical contexts, the contexts of their readers demand a greater specificity that eschews such broad/general categories. Much the same can be said about the alvar akapporul talaivi poems (the heroine of a bhakti love poem)-despite the recurring motifs of growing pale, of loosening bangles, of losing sleep, these women are different from one another. For example, when a male bhakti poet writes in the female voice about female sexuality these poems are not representations of female desire, but "representations of male attempts to aesthetically capture and portray female sexuality." 19 And in order to do so, these poets subvert akam convention (a woman riding the madal) or revert to the known conventions of akam poetry, often corralling other female characters to authenticate their experience. A female poet such as Andal uses these akam 
conventions as well (as we saw from the verse with which we began this poem), but she is distinguished from her male counterparts by the consistent use of a collective voice (we: Tiruppavai), and the lack of secondary female characters who comment on her sorry state (Nacciyar Tirumoli).

In this essay, I have argued that we can no longer speak successfully of a generic talaivi of alvar poetry. These talaivis are differentiated on multiple levels. On the most basic level is the differentiation generated by a woman speaking in a woman's voice and a man adopting a female persona. We can be attuned to the differentiation in these talaivis by a context-sensitive reading sensitive to the transparent poetics of bhakti, the systems of understanding bhakti poetry (Srivaishnava commentary, for example) and, finally, the poetic situation itself. In doing so, we come to realize that not only are there differences in the interpretations that each poet brings to their construction of their female persona, but a rich variety in the use of the female voice 'within any given poet's poetic corpus. In the case of Tirumankai's Tiruneduntandakam, the primary female voice is that of the mother, who narrates the dire situation in which she finds her daughter. Andal, our intrepid female poet, spatially calibrates her heroines: for the gopis who live in the mythic world of Vrindavana the possibility of union is always right around the corner. Their voices are playful, teasing, and intimate. But, for the lonely, bereft talaivi abandoned in the harsh environs of the "real" world, nothing is certain except her longing.

\section{Notes}

As there are no diacritics in this paper, I have attempted to remain as close to popular standard spelling and pronunciation as possible. Thus I have used Vishnu instead of Visnu (diacritics missing). However, $\mathrm{I}$ have not differentiated between long and short vowels. Thus I use Andal instead of Aandaal or Antal (without diacritics). Where I have cited work by other scholars I have retained their original spelling, but without diacritics, thus Sri Vaisnava, occurring in a citation has not been changed to either Srivaishnava or Srivaisnava. In the rest of the paper, this word occurs as Srivaishnava.

Unless otherwise indicated, all translations are mine.
2 Cankam literature refers to secular Tamil poetry composed between 1-3 CE. The poetry is broadly divided into two categories referred to as akam and puram. To put it simply, akam poems were concerned with love, while puram poems elaborated on public matters of war, ethics and kings. Tamil bhakti literature (c. 5-9 CE) borrows heavily from the conventions of the Cankam literary corpus, while adapting this secular literature to the demands of the emergent devotional literature.

3 Selby, Martha. Grow Long, Blessed Night: Love Poems from Classical India. (New York, Oxford University Press, 2000), p. 127.

${ }^{4}$ Stewart, Susan. Poetry and the Fate of the Senses. (Berkeley: University of California Press, 2003), p. 2. ${ }^{5}$ Ibid. pp. 110-115.

${ }^{6}$ This phenomenon is certainly not limited just to alvar poetry. Arguably, one can assert that the pining heroine is a standard trope of bhakti poetry that utilizes the conventions of lover and beloved.

7 Cutler, Norman and AK Ramanujan. "From Classicism to Bhakti." The Collected Essays of AK Ramanujan. (New York: Oxford University Press, 1999), p. 249.

${ }^{8}$ Ramanujan, A.K. Hymns for the Drowning. (New Delhi: Penguin Classics, 1981).

9 This is certainly not an idea exclusive to the Srivaishnava tradition and is shared by a number of Indic philosophical traditions.

10 A.K.Ramanujan. "Where Mirrors are Windows: Towards an Anthology of Reflection." The Collected Essays of A.K.Ramanujan. ed. Vinay Dharwadker. (New York: Oxford University Press. 1999), pp. 633.

${ }^{11}$ I have discussed Tirumankai's madal poems at length in another paper. I make frequent reference to the madal, which was a Cankam poetic convention, where a rejected male suitor would threaten to ride a horse made of sharp palmyra stems in public. It was act meant to shame his beloved into accepting his suit. The general consensus in the Tamil poetic grammars is that the madal could only a man could undertake the madal. However, Tirumankai composes two madal poems in which it is the rejected heroine who threatens to undertake this rather spectacular form of self-mortification. For a more detailed discussion of Tirumankai's madal poems, refer to, Venkatesan, Archana. "Riding a Horse for Love: A Comparative Look at the Madal poems of Tirumankaiyalvar and Ceyankontar. Tropes, Territories and Competing Realities. Eds. Chelva Kanakanayakàm et al. (Toronto: The Toronto South Asian Review. 2007).

${ }_{12}$ Hudson, Dennis. "Andal's Desire." Vaisnavi: Women and the Worship of Krishna. ed. 
Stephen J. Rosen. (New Delhi: Motilal Banarasidass, 1996), pp. 171-211.

${ }^{13}$ Bharati, Srirama. trans. The Sacred Book of Four Thousand. (Chennai: Sri Sadagopan

Tirunarayanswami Divya Prabandha Pathasala, 2000), p. 429.

${ }_{14}$ The girl, like the Cankam poems of old has suddenly grown-up and growing up means falling in love, with her young sexuality coming suddenly awake. She no longer wants to sit on her mother's lap to be fed; she doesn't want her dolls. Instead the girl whose rich hair decked in flowers buzzing with bees, wears the marks of one intoxicated with lovesleeplessness and constant vigilance for the lover. Thus, even though her love is extreme, the expression of that love is bound by the aesthetic conventions of how to love god like a woman, and when narrated by her mother.

${ }^{15}$ Tiruneduntandakam 22.

${ }^{16}$ Contrast to Andal and the jackal poem. Also Tirumankai chases after women in his hagiography.

${ }^{17}$ Stewart, Susan. Poetry and the Fate of the Senses. p. 138.

${ }^{18}$ Selby, Martha. Grow Long, Blessed Night. p. 100.

${ }^{19}$ Ibid. p. 104.

\section{References}

Nalayira Divya Prabandham. Tamil text. ed. Anangaracharya. (Kanci: Anangaracharya Institute, 1972).

Nalayira Divya Prabandham. Tamil text. ed. Krishnaswami Iyengar. (Trichy: Srinivasa Press.)

Bharati, Srirama. trans. The Sacred Book of Four Thousand. (Chennai: Sri Sadagopan Tirunarayanswami Divya Prabandha Pathasala; 2000).

Cutler, Norman and AK Ramanujan. "From Classicism to Bhakti." The Collected Essays of A.K.Ramanujan. ed. Vinay Dharwadker et al. (New York: Oxford University Press. 1999), pp. 232-259.

Cutler, Norman. Songs of Experience: The Poetics of Tamil Devotion. (Bloomington: Indiana University Press, 1987).

Hudson, Dennis. "Andal's Desire." Vaisnavi: Women and the Worship of Krishna. ed. Stephen J. Rosen. (New Delhi: Motilal Banarasidass, 1996), pp. 171-211.

Narayanan, Vasudha. The Way and the Goal: Expressions of Devotion in the Early Sri Vaisnava Tradition. (Washington, D.C: Institute for Vaishnava Studies and Cambridge, Mass: Center for the Study of World Religions, Harvard University, 1987).
Novetzke Christian Lee. "Divining an Author: The Idea of Authorship in an Indian Religious Tradition." History of Religions, 42.3. (Feb. 2003): pp. 213-242.

Ramanujan, A.K. "Where Mirrors are Windows: Towards an Anthology of Reflection." The Collected Essays of A.K.Ramanujan. ed. Vinay Dharwadker et al. (New York: Oxford University Press. 1999), pp. 6-33.

-..-- "Men, Women, and Saints." The Collected Essays of A.K. Ramanujan. eds. Vinay Dharwadker et al. 9New York: Oxford University Press, 1999), pp.279-294.

------. Hymns for the Drowning. (New Delhi: Penguin Classics, 1981).

Selby, Martha. Grow Long, Blessed Night: Love Poems from Classical India. (New York, Oxford University Press, 2000) 